ECONOMIC THEMES (2020) 59(3): 297-314

DOI 10.2478/ethemes-2021-0017

\title{
NATIONAL INNOVATION CAPACITY AND ECONOMIC PROGRESS OF COUNTRIES
}

\author{
Slobodan Cvetanović \\ University of Nis, Faculty of Economics, Republic of Serbia \\ $\checkmark$ slobodan.cvetanovic@eknomski.rs

\section{Andrea Andrejević Panić} \\ University of Educons, Sremska Kamenica, Republic of Serbia \\ $\triangle$ andrea.andrejevic@educons.edu.rs \\ Aleksandar Kostić \\ University of Pistina - Kosovska Mitrovica, Faculty of Economics, \\ Republic of Serbia \\ $\triangle$ aleksandar.kostic@pr.ac.rs
}

UDC

$001.895+$

330.341

Review paper

Received: 22.04.2021

Accepted:

02.07 .2021

\begin{abstract}
The ability of the national economy to create and to valorize innovations on the market in order to produce economic goods represents its national innovation capacity, which is at the same time a key determinant of countries' economic progress. Due to this fact, its relevance imposes the task of identifying, as accurately as possible, the key theoretical postulates on which this concept is based, as well as calculating the Innovation capacity index by which it is possible to predict progress in building innovation capacity of individual countries and mutual comparison with other countries according to innovation capabilities. After a brief explanation of the essence of learning, on which this concept is based, an attempt is made to calculate the Innovation capacity of the European Union and the Western Balkans, on the one hand, and to consider the interdependence of the obtained results and the achieved level of their economic development in 2020, on the other hand. The results of the research confirmed the strong connection between the Innovation capacity index and the achieved level of economic development of countries expressed in terms of gross domestic product per capita.
\end{abstract}

Keywords: national innovation capacity, national innovation system, Innovation capacity index, knowledge, innovation, EU, The Western Balkans

JEL classification: 03 


\section{Introduction}

In a world that is increasingly transforming, the importance of innovation and the imperative to increase the national innovation capacity (NIC) is becoming more evident every day. Therefore, the growth of NIC, as an important prerequisite for successful adaptation of society to increasingly rapid scientific, technological and economic changes, becomes the main topic nowadays. (Cvetanović et al., 2015)

A common problem in researching the economic aspects of the phenomenon of innovation is their identification with phenomena such as invention and inventiveness, creation and creativity. In that sense, it should be noted that these are content-wise different phenomena with unique and specific meanings. In short, invention represents the birth of an idea for the emergence of a new product or process or something else, while innovation means its material embodiment that experienced its first market commercialization. Inventiveness is, therefore, the process of giving birth to a new idea regarding the emergence of something new, that is, a process that contributes to increasing the total fund of human knowledge. Creativity is thinking about new things and phenomena in a new and constructive way. It represents an opportunity to create a new look, content or process by combining existing factors of production (Cvetanović, \& Nedić, 2018).

The structure of the NIC consists of the innovation infrastructure of the economy, the innovation environment, innovation and industrial clusters and the links between the common innovation infrastructure and the cluster. The innovation infrastructure of the economy consists of a number of interrelated factors that stimulate the growth of innovation in various areas of the economy, including human and financial resources dedicated to scientific and technological progress, the application of economic policy instruments that stimulate the emergence and widespread use of various innovative solutions in the economy and society. The basis of the country's innovation infrastructure is its scientific and research staff, whose activities dominantly contribute to the growth of NIC.

The development and commercialization of new technologies not infrequently occurs in clusters, groups of companies and institutions that are interconnected in a particular geographical area. Presence in the cluster gives companies the opportunity to see the needs and opportunities for innovation.

The quality of connections that exist between the innovation infrastructure and individual industrial clusters is of particular importance for the dynamics of innovative activities. Clusters store common infrastructure, and at the same time benefit from it. Without strong ties, scientific and technical advances can be dispersed and transferred to other countries instead of being used at home. Entrepreneurial universities have an extremely important role in connecting, which has the role of bridging the gap between researchers and companies (Ješić, Okanović \& Andrejević Panić, 2019). 
Starting from the previously explicit statements about the importance of continuous increase of NIC, we determine the goal of the work in terms of: a) an attempt to calculate Innovation capacity index (ICI) by which it is possible to compare progress in NIC construction over time, and also compare achievements in NIC construction of different countries; b) consideration of the interdependence of ICI of individual countries and the level of their economic development expressed in terms of gross domestic product per capita (GDP pc).

The structure of the work consists of five parts. The first part, which has an introductory character, discusses the subject and purpose of the research. The second part gives a brief overview of the theoretical pillars of the NIC concept. The third part of the paper is dedicated to explaining the physiology of economic growth as undoubtedly the most important indicator of macroeconomic dynamics and the achieved level of economic development of countries. In the fourth part, the ICI of selected European countries is calculated based on its own methodology using World Bank data. In the fifth part, concluding remarks are presented.

\section{Theoretical basis of the NIC concept}

NIC means the ability of the national economy to use existing and create new knowledge in the process of creating economic values. Economic progress embodied in the achieved level of GDP pc in modern conditions implies continuous commercial valorization of knowledge into innovations, regardless of the fact that it is a matter of simple improvements of products, services or processes, or it is about disruptive inventions.

Although the explication of the main theoretical pillars of NIC is far from an easy task, our opinion is that it can be satisfactorily represented by looking at the messages of three very well-known teaching concepts: a) Paul Romer's (1986) model of endogenous economic growth, b) Michael Porter's model of competitive advantage (1990) and c) the concept of a national innovation system (NIS) by Chrystofer Freeman (1987), Bengt-Åke Lundvall (1992) and Richard Nelson (1993).

\subsection{A model of economic growth based on the ideas of Paul Romer}

Paul Romero's growth model starts from the premise that ideas, i.e., knowledge in a broader context, enable growing yields, which is understandably not in line with the assumptions of perfect competition, which was the basic analytical starting point of previously dominant exogenous model presentations of economic growth. In other words, innovations are a product of the economic system and analogous to that fact, during the market valorization of their effects, market irregularities often appear, which calls into question one of the basic theoretical premises of neoclassical economists. This is the main reason why the knowledge that marks the 
key generator of innovation possesses the characteristics of public goods. Namely, these concepts of knowledge are often very difficult to obtain, but they can be reproduced very cheaply. Since private economic agents are not able to take full advantage of the accumulation of ideas (knowledge), the rate of economic growth is inevitably at a lower level compared to the socially possible one, which is achieved exclusively by the active role of the state. Therefore, states must provide researchers and innovators with appropriate incentives so that they are ready to continue with activities that ultimately result in market valorization of knowledge into innovation (Švarc, 2009).

Romer explains the physiology of innovation in the economy by the indisputable need of researchers and innovators to make a profit through the commercial valorization of new ideas (Romer, 1987). Unlike neoclassical models of economic growth that can be applied to different countries, Romero's model basically describes developed economies as a whole. Innovations are predominantly enabled by the results of fundamental and applied research in the developed world (Cvetanović, \& Despotović, 2014).

The results of research and development have the characteristics of public goods, i.e., they are characterized by non-competitiveness. Instead of perfect competition as an environment in which economic entities optimize their target functions, supporters of endogenous explanations of economic growth see imperfect competition as a reality in which businesses and consumers make their decisions. Instead of declining returns, non-declining returns are counted in endogenous explanations of economic growth. They also emphasize the importance of a monopoly on applicable knowledge in order to preserve people's interest in engaging in these activities. An economy in which there is a lack of physical capital and / or lack of natural resources suffers from the so-called "resource gap". On the contrary, a country which lack knowledge has a pronounced "idea gap" (Jones, 1990, p. 89).

The amount of costs allocated to research and development activities depends not only on their market effects, but also on the possibility of preserving, even a temporary monopoly over them (Blanchard, 2005). Assuming that research and development activities result in a large number of new products (processes), companies are more motivated to invest more in innovation activity. It is understandable that in this case the intensity of technological changes at the macro level will be more evident. What should be borne in mind in this case, however, is the fact that many determinants of R\&D success are located outside the realm of economics. The efficiency of research depends on the successful interaction of basic and applied research, and it should be borne in mind that basic research does not inevitably lead to innovation. However, the success of applied and development research ultimately depends on the results of basic research. 
The key message of Romero's models of endogenous growth for the NIC improvement strategy is that, providing the conditions that the possibility of appropriating the effects based on the commercialization of knowledge into various innovative solutions implies the existence of a maker monopoly over time. In this context, there is a possibility of manifesting battle conflicts between different ways of increasing NIC. Some of these conflicts are the result of the search for new knowledge that works in the direction of creating monopoly situations, while others imply the unhindered expansion of available knowledge, and thus the weakening of existing monopolies. The possible role of the state would be to mediate between these opposing needs by creating framework rules and incentives for new knowledge without preventing their spread (Acocella, 2005, p. 168).

\subsection{Michael Porter's model of competitive advantage of nations}

Michael Porter believes that national prosperity is created, not inherited, which means that it is not the result of the country's availability of natural resources and labor, as claimed by economists of classical provenance. The competitiveness of a country depends on the ability of its economy to innovate and to realize continuous improvements in all domains of business activity. This gives the companies an advantage over other world competitors. In order to be competitive, companies must have strong domestic competitors, responsible suppliers in their country, and demanding local consumers (Porter, 1990).

Michael Porter's key commitment is that innovation drives and supports competition. The company must use all dimensions of competition that signify a kind of diamond (rhombus) of national competitiveness. The basic determinants of the competitiveness of individual countries are:

a) conditions related to factors of production that determine the dynamics and manifestations of competition in certain areas of business (capital, level of technology, infrastructure, skilled labor, available information, etc.),

b) conditions related to the internal demand for goods and / or services of the given production areas,

c) the presence or absence of supply and other related competing industries in the country,

d) the conditions in the country that determine how companies are established, organized and run, as well as the nature of domestic rivalry (Porter, 1990).

The availability of factors of production determines a country's capacity to compete in a particular industry. Porter says that although these factors are important for the quality of production and trade, they still do not have such importance as the representatives of classical economic thought attached to them. 
The most important factor of competitiveness means the country's ability to continuously create, improve and develop its own factors (such as skilled labor).

The company must face competition in the domestic market. Successful competitors are more likely to be those firms that survive and thrive in an increasingly demanding market. According to Porter, the most important dimension of the market is its ability to promote the growth of the company's competitiveness. Competitive companies depend on the national environment in which they operate. Some national economies support competitiveness more than others, while others do not. A company that operates within a group of related companies and industries realizes and continuously maintains an advantage through similar operations.

The third factor of competitive advantage according to Michael Porter refers to related and ancillary activities. It implies competition between all related industries and the firm's suppliers. Constant and close interaction is successful in cases when it is not the result of real physical proximity, but is reflected in the willingness of companies to work on it.

The conditions in the country that determine the process of establishing an organization and running a company, as well as the nature of domestic rivalry, are also extremely important in determining the competitiveness of individual countries.

According to Michael Porter, success is achieved by those countries where the process of interaction of all factors of national competitive advantage is the most dynamic. This is especially true in the field of innovation, where success cannot be achieved if one of the mentioned determinants of diamond does not give its full contribution.

In this conception, the diamond maximum implies the existence of two more conditions, the influence of which is essential in the process of shaping international development advantages. These are: development policy of the state and accidental circumstances. Economic policy will be successful provided that there are other preconditions for creating competitive advantages of nations and where its instruments only strengthen the action of the elements that make up the national diamond.

The key message of Porter's model of competitive advantage of nations for the concept of innovation capacity of the economy is that companies achieve competitive advantage and extra profit thanks to innovation. Their approach to innovation is very diverse. They find a new basis for application or new ways for applying on the old basis. Innovations can include a new product design, a new production process, a new market approach or a new way of training. 


\subsection{NIS concept}

NIC research is most directly related to the emergence of the NIS concept in the 1990s not only in the academic works of the British economist Freeman (1987), the Swedish scientist Lundvall (1992) and the American economist Nelson (1993), but also in their practical activities focused on its affirmation. These researchers saw the emergence and diffusion of innovation in a diametrically different way compared to the hitherto prevailing approach of the neoclassicists (Soete, Verspagen, \& Ter Weel, 2010). Contrary to the opinions of neoclassicists, they believe that the efficiency of managing innovation processes at the national level means primarily a social process of endogenous character.

Freeman (1987) defines a national innovation system as a network of private and public institutions that interact to initiate, import, modify, and spread innovation. Mowery \& Oxley (1995) think similarly, according to which NIS consists of a network of public and private institutions that create and transform the results of scientific research into innovation.

There is almost no concept in science and technology that has experienced a similar rise in professional and political circles, as the case with NIS (Albert, \& Laberge, 2007). The reason for this fact, in addition to the content flexibility, was certainly the practical applicability of the concept as a valuable analytical tool used in the research of numerous economic problems. It is this fact that has made the NIS concept an extremely useful framework for analyzing significant and complex issues related to the economic development process (Freeman, 1987).

One group of researchers believes that each country has its own NIS, while another, on various grounds, argues that the issue involves meeting certain conditions. According to Freeman (1987), every country has NIS, and in some environments, they are efficient, while in others they are not. Some of them are of embryonic character, but still exist (Malerba, 2002). For another group of researchers, the definition of NIS implies the existence of quality institutions. Only under the condition that the institutions which make up the structure of NIS are satisfactorily developed, it makes sense to talk about its existence (Smith, 1997). Without going into a more detailed elaboration of this issue on this occasion, the authors of this paper are closer to the position that each country has its own NIS. The second question is whether it is satisfactorily effective (Cvetanović, \& Novaković, 2014).

The NIS concept emphasizes the importance of interactions between participants in the innovation process and looks at the ways in which these processes are shaped under the influence of a large number of social, institutional and political factors (Fagerberg \& Verspagen, 2009). The approach has proven to be very successful over the past thirty years and has been used frequently in a variety of scientific, as well as political contexts. 
In economic theory, it is possible to find different explanations for the success of the NIS concept. Thus, for example, some explanations highlight its conceptual advantages as an important tool in the analysis of the innovation of national economies, while others primarily indicate the social character of its application.

The structure of NIS consists of a large number of market and non-state institutions whose functioning represents a kind of framework for governments when designing and implementing numerous measures to stimulate innovation activities (Fagerberg, \& Verspagen, 2009). A special place in the processes of adaptation to change belongs to continuous learning. This also shows the connection of NIS with human resources management, labor market, companies' capacity to learn.

Efficient NIS are able to create an environment conducive to the continuous production of knowledge and especially the commercial valorization of knowledge into innovation. Understandably, the institutional environment, which inefficiently coordinates the interactions of entities in innovation processes, can cause the failure of the entire NIS.

An important element of NIS is social capital, the most important component of which is trust. It has been proven that the level of development of institutions in the system corresponds to the level of trust in society. In turn, trust has a positive impact on the efficiency of NIS functioning. This is for the simplest reason that trust reduces the risk posed by the inevitable companion of innovation activities, and in particular reduces the risk associated with funding research and innovation processes (Smith, 1997).

The NIS concept is an unavoidable part of modern strategies of economic and social development, both in developed and developing countries. A society that learns and successfully adopts knowledge is considered to be the most important resource of the innovation system. In doing so, learning is its central mechanism. (Soete, Verspagen, \& Ter Weel, 2010).

Recognizing in innovation a kind of development resource, most economists today believe that the management of this system becomes one of the essential aspects of the efficiency of the functioning of individual economies as a whole. The growing importance of innovation in business requires that the issue of optimal management be raised with the necessary seriousness at all levels, from the highest, macro level, to the level of individual companies.

\section{Economic growth as a prerequisite for economic progress of countries}

Economic growth implies a higher value of production and services in the observed time interval compared to some earlier period. Economic development includes the 
content of economic growth and numerous structural, institutional and technological changes, as well as raising the living standards of the population (Cvetanovic, 2005). The increase in the value of production, at the level of the national economy, is expressed by the increase in gross domestic product per capita. Every economy strives for long-term economic growth for the basic reason that without economic growth, in a longer period of time, the possibility of increasing the living standard of the population is practically impossible. Due to their precision, economic growth indicators represent applied and almost irreplaceable analytical categories in the largest number of macroeconomic analyzes. Many economists believe that economic growth is the most important factor in the development of the national economy, especially when it comes to countries with a lower level of economic development. With a low initial level of development and continuous growth of the population, overcoming poverty without increasing material production is impossible. Stable economic growth is an important prerequisite for easier solution of the central economic task in each community, defined as an effort to meet the growing needs of people as much as possible by using always limited resources (Cvetanović \& Mladenović, 2015).

Innovation is a central driver of economic growth, competitiveness and the creation of better jobs. It is a factor that enables companies to compete successfully in the global market. It is a process that seeks solutions to social and economic challenges, from climate change to the fight against deadly diseases. Innovation is a source of improving the quality of people's daily lives.

\section{Methodology and research}

The research hypothesis is as follows: There is a strong link between ICI and the achieved level of economic development of countries expressed in terms of GDP pc of both EU countries and the Western Balkans.

Quantification of NIC in this paper was realized by calculating the value of ICI, which indicates the average of the sums of Research capacity index, Technology and innovation efficiency index and Knowledge and technology absorption and diffusion index (See Table 1). In addition, the Research capacity index means the average sum of the Research and development index, the Tertiary education index and the Scientific and technical publications index; Technology and innovation efficiency index means average sum of Patent applications index, Royalties and license fees receipts index and Trademark applications index, while Knowledge and technology absorption and diffusion index represents average Knowledge absorption index and Knowledge diffusion index (see Tables 2, 3 and 4 in the Annex of the work).

To calculate these variables in order to take values from zero to one hundred, the method of variable transformation is used: 


$$
\mathrm{x}-\text { index }=\frac{\mathrm{x}-\min (\mathrm{x})}{\max (\mathrm{x})-\min (\mathrm{x})} \mathrm{x} 100
$$

\begin{tabular}{|c|c|c|c|c|}
\hline & $\begin{array}{c}\text { Research } \\
\text { capacity } \\
\text { index }\end{array}$ & $\begin{array}{l}\text { Technology and } \\
\text { innovation } \\
\text { efficiency index }\end{array}$ & $\begin{array}{c}\text { Knowledge and } \\
\text { technology } \\
\text { absorption and } \\
\text { diffusion index }\end{array}$ & $\begin{array}{c}\text { Innovation } \\
\text { capacity } \\
\text { index }\end{array}$ \\
\hline Austria & 60.7 & 50.8 & 39.3 & 50.2 \\
\hline Belgium & 53.4 & 35.8 & 39.0 & 42.7 \\
\hline Bulgaria & 25.1 & 47.1 & 34.0 & 35.4 \\
\hline Cyprus & 42.5 & 22.1 & 47.3 & 37.3 \\
\hline Czech R. & 45.8 & 52.2 & 38.3 & 45.4 \\
\hline Germany & 57.4 & 74.5 & 44.2 & 58.7 \\
\hline Denmark & 72.4 & 50.7 & 41.7 & 54.9 \\
\hline Spain & 48.3 & 33.0 & 34.9 & 38.7 \\
\hline Estonia & 50.9 & 32.0 & 37.3 & 40.1 \\
\hline Finland & 68.5 & 68.0 & 55.1 & 63.9 \\
\hline France & 50.7 & 76.2 & 48.6 & 58.5 \\
\hline Greece & 51.2 & 12.6 & 23.4 & 29.1 \\
\hline Croatia & 39.3 & 29.7 & 29.8 & 32.9 \\
\hline Hungary & 38.5 & 38.8 & 46.4 & 41.2 \\
\hline Ireland & 44.8 & 34.0 & 73.4 & 50.7 \\
\hline Italy & 43.0 & 42.4 & 33.0 & 39.5 \\
\hline Lithuania & 37.5 & 24.6 & 27.0 & 29.7 \\
\hline Luxembourg & 34.9 & 64.2 & 45.5 & 48.2 \\
\hline Latvia & 29.0 & 35.4 & 36.9 & 33.8 \\
\hline Malta & 22.7 & 55.6 & 39.9 & 39.4 \\
\hline Netherlands & 53.7 & 58.4 & 78.8 & 63.6 \\
\hline Poland & 38.6 & 35.0 & 37.4 & 37.0 \\
\hline Portugal & 56.5 & 39.3 & 28.9 & 41.6 \\
\hline Romania & 26.2 & 35.2 & 38.9 & 33.4 \\
\hline Slovak R. & 29.4 & 26.3 & 33.4 & 29.7 \\
\hline Slovenia & 61.4 & 64.9 & 33.0 & 53.1 \\
\hline Sweden & 67.4 & 56.9 & 57.5 & 60.6 \\
\hline Albania & 12.8 & 18.3 & 15.6 & 15.5 \\
\hline$B \& H$ & 18.1 & 14.8 & 20.5 & 17.8 \\
\hline N. Macedonia & 18.7 & 42.9 & 21.3 & 27.6 \\
\hline Montenegro & 31.7 & 8.5 & 20.4 & 20.2 \\
\hline Serbia & 46.6 & 28.5 & 29.2 & 34.8 \\
\hline
\end{tabular}

Table 1: ICI of EU and Western Balkan countries in 2020.

Source: author's calculation according to World Bank data 
In the European Union, Finland had the highest ICI values in 2020, followed by the Netherlands, Sweden, Germany and France. The countries of the Western Balkans (Albania, Bosnia and Herzegovina, North Macedonia and Montenegro), which are in various stages of the process of accession to the European Union, lag significantly behind all EU member states. Among these countries, Serbiahad the largest NIC, which according to the values of the innovation capacity index of 34.8 exceeds 6 EU member states (Latvia -33.8, Romania - 33.4, Croatia - 32.9, Lithuania - 29.7, Slovak Republic - 29.7 and Greece - 29.1).

Graph 1: Innovation capacity index of EU and Western Balkan countries in 2020

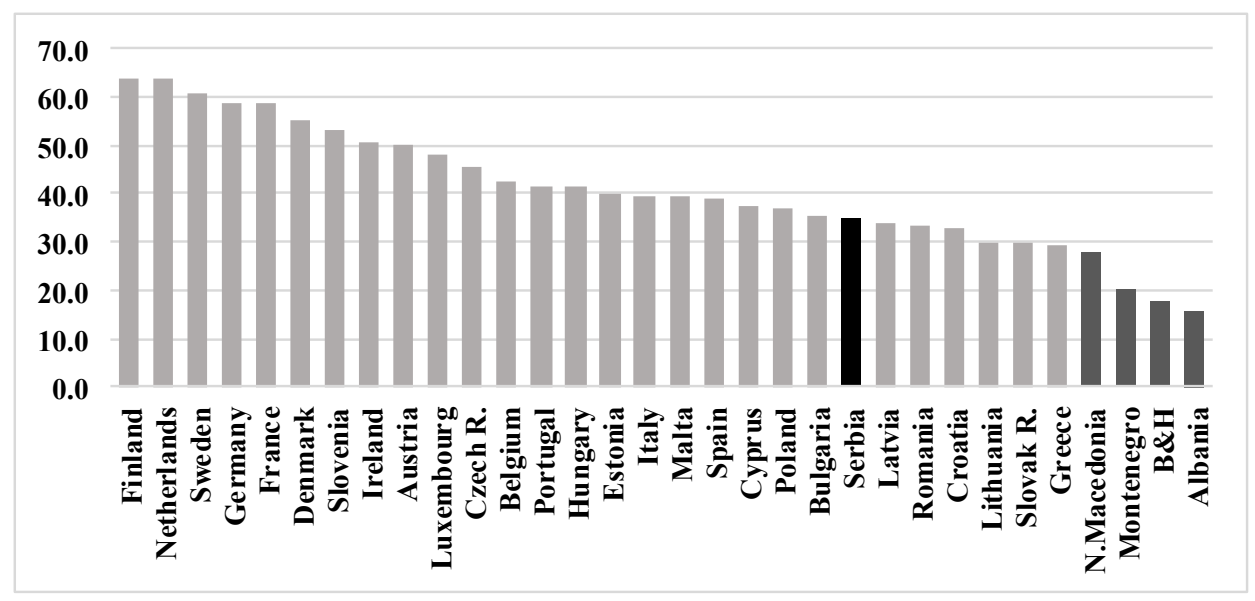

Source: author's calculation according to World Bank data

Albania has the lowest innovation capacity of the Western Balkans, Bosnia and Herzegovina and Montenegro have a slightly higher innovation capacity, and according to the height of ICI, Northern Macedonia is very close to Lithuania, Slovak Republic and Greece, countries at the very bottom of the European Union in terms of NIC. Relatively important NIC of Serbia, observed not only in relation to other countries of the Western Balkans, but also in relation to a number of EU countries, allows Serbia more significant involvement in the global race for development and implementation of innovations and thanks to that, in a relatively short period of time, technological growth.

Although all Western Balkan countries lag far behind in economic development, not only behind the leading EU countries and the EU average, but also in relation to the least developed EU countries (Latvia, Greece, Romania, Croatia and Bulgaria), the development of their NICs gives them a chance to accelerate technological progress and intensification of development dynamics on that basis, which would create objective conditions for accelerating the process of economic convergence with EU members. 
The relationship between the value of ICI and the achieved level of economic development of countries measured by the size of GDP per capita is presented in Graph 2. It can be seen that the value of ICI is strongly correlated with the level of GDP pc. Improving innovation capacity is key to achieving high levels of GDP pc. The largest number in the work of the observed countries follows the regression line from the total sample.

\section{Graph 2: ICI and GDP pc PPP \$ of EU and Western Balkan countries in 2020}

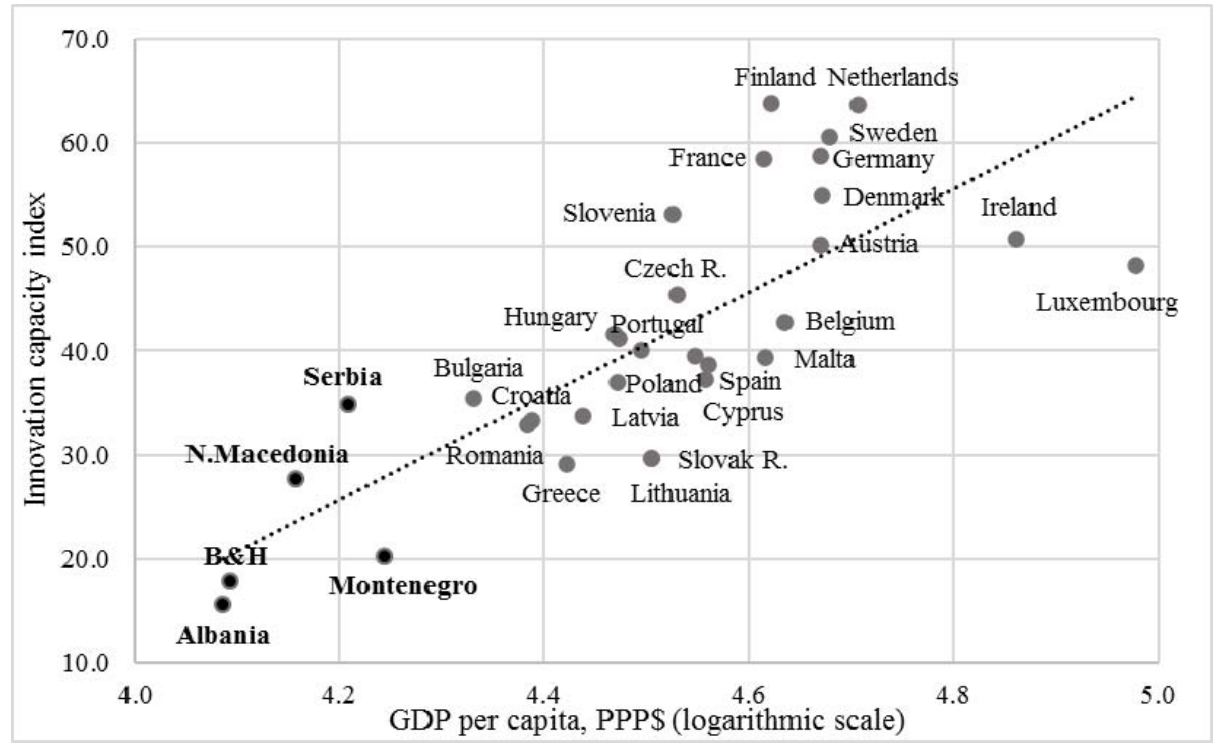

Among the countries of the Western Balkans in 2020, Serbia showed a relatively significant ICI, observed not only in relation to other countries in the region, but also in relation to countries that have been members of the EU for a long time, such as Greece. This fact could potentially enable Serbia to be more effectively involved in the global race for development in the environment of the knowledge economy.

\section{Conclusion}

Innovation has become the most important factor in the economic progress of countries in modern economic conditions. The countries with the highest NIC are at the same time the countries with the largest new GDP pc. The countries that occupy this position are Finland, the Netherlands, Sweden and Denmark in the EU. Among the EU countries, Ireland and Luxembourg have relatively modest innovation potential and the highest level of GDP pc PPP \$, which suggests that 
they came to an extremely high level of GDP pc PPP \$. This occurs thanks to some other drivers of economic growth.

The construction of the NIC has a strong connection with the achieved level of economic development. The offered framework for NIC analysis in the paper relies on World Bank data. The obtained ICI values enable the ranking of countries, depending on the knowledge of this index, as well as the understandable ranking of countries depending on the size of its three components: Research capacity index, Technology and innovation efficiency index and Knowledge and technology absorption and diffusion index.

The ranking identified the economies in the EU that have made the most progress in building NICs. These are Finland, the Netherlands and Sweden. In contrast, low NIC levels certainly have a limiting effect on GDPpc growth in countries such as Greece and Romania.

Improving the NIC for the five Western Balkan countries will be a major development challenge in the years to come. Their current lag in the construction of NICs for EU countries is very pronounced. At the same time, according to the ICI value, Northern Macedonia and especially Serbia reduced their lag behind the EU members at the end of 2020. In this regard, the largest lag in the construction of NIC among the countries of the Western Balkans is present in Albania and Bosnia and Herzegovina.

\section{References}

Acocella, N. (2005) Počela ekonomske politike: vrijednosti i tehnike. Zagreb: Mate.

Albert, M. \& Laberge, S. (2007) The Legitimation and Dissemination Processes of the Innovation System Approach: The Case of the Canadian and Quebec Science and Technology Policy, Science, Technology \& Human Values, 32(2): 221-249

Blanchard, O. (2005) Makroekonomija, Mate, Zagreb.

Carlsson, B., Jacobsson, S., Holmén, M., \& Rickne, A. (2002) Innovation systems: analytical and methodological issues. Research policy, 31(2): 233-245.

Cvetanović, S., \& Nedić, V. (2018) Inovacija kao razvojni resurs. Niš: Ekonomski fakultet Univerziteta u Nišu.

Cvetanović, S., \& Mladenović, I. (2015) Ekonomija kapitala i finansiranje razvoja. Niš: autorsko izdanje.

Cvetanović, S. (2005) Teorija privrednog razvoja. Niš: Ekonomski fakultet u Nišu.

Cvetanović, S., \& Despotović, D. (2014) Znanje kao komponenta ljudskog kapitala u modelima ekonomskog rasta. Škola biznisa, 1. 1-17.

Cvetanović, S., Ilić, V., Despotović, D., \& Nedić, V. (2015) Knowledge Economy Readiness, Innovativeness and Competitiveness of the Western Balkan Countries. Industrija, 43(3): 27-53.

Cvetanović, S., Ilić, V., Despotović, D. (2017) Ljudski kapital i endogeni razvoj regiona. Teme, 41 (1), 73-90.

Fagerberg, J., \& Verspagen, B. (2009) Innovation studies -The emerging structure of a new scientific field. Research policy, 38 (2), 218-233. 
Freeman, C. (1987) Technology policy and economic policy: Lessons from Japan. London: Pinter.

Ješić, J., Okanović A. \& Andrejević Panić, A. (2019) Possibilities for Quadruple Helix Model Approach in an Inclusive Regional Innovation Systems. Proceedings of 1st Virtual International Conference (PaKSom 2019): Path to a Knowledge Society-Managing Risks and Innovation. Eds: Stanković, M. \& Nikolić, V., Research and Development Center "IRC ALFATEC" and Complex System Research Centre, Niš, December 09-10, Serbia, 181-188.

Jones, C. (1990) Introduction to Economic Growth, Norton and Company.

Lundvall, B. A. (1992) National Systems of Innovation: An analytical framework. London: Pinter.

Malerba, F. (2002) Sectoral systems of innovation and production. Research policy, 31(2): 247-264.

Mowery, D., \& Oxley, J. (1995) Inward technology transfer and competitiveness: the role of national innovation systems. Cambridge journal of economics, 19(1): 67-93.

Nelson, R. (ed). (1993) National Innovation Systems: a Comparative Study, New York: Oxford University Press.

Porter, M. E. (1990). The Competitive Advantage of Nations. Free Press, New York.

Romer, P. (1986) Increasing returnsand long run growth, Journal of Political Economy, 94, 1002-1037.

Romer, P. (1987) Growth Based on Increasing Returns and Long-run Growth, Amercan Economic Review, 94, 56-62.

Smith, K. (1997) Economic infrastructures and innovation systems. Systems of innovation: Technologies, institutions and organisations, 86-106.

Soete, L., Verspagen, B., \& Ter Weel, B. (2010) Systems of Innovation, Handbook of the Economics of Innovation, Elsevier.

Švarc, J. (2009) Hrvatska u društvu znanja: prijepori i perspektive inovacijske politike. Zagreb: Školska knjiga.

\section{NACIONALNI INOVACIONI KAPACITET I EKONOMSKO NAPREDOVANJE ZEMALJA}

Apstarkt: Sposobnost nacionalne ekonomije da kreira i tržišno valorizuje inovacije u cilju proizvodnje ekonomskih dobara označava njen national innovation capacity, koji je istovremeno ključna determinantua ekonomskog napredovanja zemalja. Zbog te činjenice, svojm aktuelnošću se nameće zadatak što je moguće preciznijeg prepoznavanja ključnih teorijskih postulata na kojima se ovaj koncenpt temelji, kao i izračunavanje Innovation capacity index pomoću koga je moguće upređivati napredak u izgradnji inovacionog kapaciteta pojedinih zemalja i međusobnu komparaciju sa drugim zemljama po kriterijumu inovacione sposobnosti. U radu je nakon sažete eksplikacije suštine učenja na koja se temelji ovaj koncept, učinjen pokušaj obračunavanja Innovation capacity država Evropske unije i zemalja Zapadnog Balkana, s jedne, i sagledavanja međuzavisnosti dobijenih rezultata i dostignutog nivoa njihove ekonomske razvijenosti iskazane visinom bruto domaćeg proizvoda po stanovniku u 2020. godini, s druge strane. Rezultati istraživanja su potvrdili snažnu vezu Innovation capacity index i dostignutog nivo ekonomske razvojenosti zemalja iskazane visinom GDP per capita.

Ključne reči: nacionalni inovacioni kapacitet, nacionalni inovacioni sistem, znanje, inovacija, EU, Zapadni Balkan 


\section{Authors' biographies}

Slobodan Cvetanović is a full professor at the Faculty of Economics, University of Niš. He graduated from the Faculty of Economics at the University of Niš and received his master's and doctoral degrees from the Faculty of Economics, at the University of Belgrade. He also completed postgraduate specialist studies at the Faculty of Law, University of Nis - in the field of finance. As a scholarship holder of the former USSR Government, he was on professional training in the field of international economics in 1988/89 at the Faculty of Economics of the State University of St. Petersburg. He is the author and co-author of more than 500 papers published in leading domestic and world scientific and professional journals. He has participated in more than 70 scientific conferences in the country and abroad. He is the author and co-author of about 40 monographs, books and textbooks. His areas of scientific interest are: macroeconomic theory and policy, theory and policy of economic development, economics of sustainable development, economics of innovation, economics of capital and financing of development, economics of health.

Andrea Andrejević Panić, PhD, is an Assistant Professor at the Faculty of Business Economics at Educons University, Serbia. She holds a Ph.D. degree in economics from Educons University since December 2016. She is active in publishing scientific papers and involved in several scientific projects. Her main research interests include macroeconomics of transition economies, economic development, international finance, and financial management. Other research interests include: Economic sciences, Development economics, Sustainable development, Higher education. She is a member of the team for university - industry cooperation and a coordinator for development and transformation processes at the University Rectorate.

Aleksandar Kostic is an associate professor of sociology at the Faculty of Economics in Prishtina - Kosovska Mitrovica. He graduated at the Faculty of Law in Nis, where he earned his doctorate. The basic fields of his research include economic sociology, sociology of globalization and sociology of law. In particular, he studied the management of global social change, socio-cultural conflicts and sustainable development, national identity in the context of globalization, futurological aspects of globalization. He is a member of the European Sociological Association, the Serbian Sociological Society and the author of several original scientific papers that he has published in the country and abroad. He is a participant in a number of international scientific conferences. He is the author and co-author of four monographs. 


\section{Appendix}

Table 2: Research capacity index of $\mathrm{EU}$ and Western Balkan countries in 2020

\begin{tabular}{|c|c|c|c|c|}
\hline & $\begin{array}{l}\text { Research and } \\
\text { development } \\
\text { inex }\end{array}$ & $\begin{array}{l}\text { Tertiary } \\
\text { education } \\
\text { index }\end{array}$ & $\begin{array}{l}\text { Scientific and } \\
\text { technical } \\
\text { publications } \\
\text { index }\end{array}$ & $\begin{array}{c}\text { Research } \\
\text { capacity } \\
\text { index }\end{array}$ \\
\hline Austria & 58.2 & 62.40 & 61.4 & 60.7 \\
\hline Belgium & 59.6 & 38.40 & 62.2 & 53.4 \\
\hline Bulgaria & 12.1 & 37.40 & 25.7 & 25.1 \\
\hline Cyprus & 6.5 & 48.00 & 73.0 & 42.5 \\
\hline Czech R. & 27.4 & 45.50 & 64.6 & 45.8 \\
\hline Germany & 72.7 & 56.10 & 43.5 & 57.4 \\
\hline Denmark & 71.8 & 45.30 & 100.0 & 72.4 \\
\hline Spain & 44.9 & 43.90 & 56.0 & 48.3 \\
\hline Estonia & 23.9 & 48.40 & 80.3 & 50.9 \\
\hline Finland & 65.7 & 52.20 & 87.7 & 68.5 \\
\hline France & 64.4 & 45.40 & 42.2 & 50.7 \\
\hline Greece & 31.3 & 64.60 & 57.6 & 51.2 \\
\hline Croatia & 11.8 & 41.30 & 64.8 & 39.3 \\
\hline Hungary & 35.3 & 37.70 & 42.4 & 38.5 \\
\hline Ireland & 52.5 & 47.50 & 34.3 & 44.8 \\
\hline Italy & 44.1 & 37.60 & 47.3 & 43.0 \\
\hline Lithuania & 18.8 & 42.70 & 51.0 & 37.5 \\
\hline Luxembourg & 35.6 & 34.50 & 34.5 & 34.9 \\
\hline Latvia & 12.0 & 44.50 & 30.4 & 29.0 \\
\hline Malta & 8.5 & 34.70 & 24.9 & 22.7 \\
\hline Netherlands & 65.8 & 36.20 & 59.0 & 53.7 \\
\hline Poland & 32.8 & 37.90 & 45.2 & 38.6 \\
\hline Portugal & 39.0 & 45.50 & 85.1 & 56.5 \\
\hline Romania & 7.0 & 39.80 & 31.7 & 26.2 \\
\hline Slovak Republic & 16.5 & 32.20 & 39.5 & 29.4 \\
\hline Slovenia & 40.0 & 44.90 & 99.4 & 61.4 \\
\hline Sweden & 74.0 & 44.90 & 83.3 & 67.4 \\
\hline Albania & 1.2 & 29.30 & 7.8 & 12.8 \\
\hline$B \& H$ & 2.3 & 32.00 & 20.1 & 18.1 \\
\hline N.Macedonia & 5.0 & 27.30 & 23.9 & 18.7 \\
\hline Montenegro & 4.0 & 40.70 & 50.5 & 31.7 \\
\hline Serbia & 11.6 & 43.70 & 84.5 & 46.6 \\
\hline
\end{tabular}

Source: author's calculation according to World Bank data 
Cvetanović et al. / Economic Themes, 59(3): 297-314

Table 3: Technology and innovation efficiency index of $\mathrm{EU}$ and Western Balkan countries in 2020

\begin{tabular}{|c|c|c|c|c|}
\hline & $\begin{array}{c}\text { Patent } \\
\text { applications } \\
\text { index } \\
\end{array}$ & $\begin{array}{l}\text { Royalties and } \\
\text { license fees } \\
\text { receipts index }\end{array}$ & $\begin{array}{c}\text { Trademark } \\
\text { applications } \\
\text { index } \\
\end{array}$ & $\begin{array}{l}\text { Technology and } \\
\text { innovation } \\
\text { efficiency index }\end{array}$ \\
\hline Austria & 42.3 & 40.2 & 69.8 & 50.8 \\
\hline Belgium & 11.5 & 50.3 & 45.5 & 35.8 \\
\hline Bulgaria & 17.1 & 12.6 & 111.5 & 47.1 \\
\hline Cyprus & 0.4 & 3.1 & 62.7 & 22.1 \\
\hline Czech R. & 24.6 & 22.5 & 109.5 & 52.2 \\
\hline Germany & 100.0 & 57.2 & 66.3 & 74.5 \\
\hline Denmark & 41.9 & 62.8 & 47.4 & 50.7 \\
\hline Spain & 15.0 & 26.9 & 57.0 & 33.0 \\
\hline Estonia & 5.4 & 9.7 & 81.0 & 32.0 \\
\hline Finland & 55.7 & 83.9 & 64.3 & 68.0 \\
\hline France & 44.1 & 63.6 & 121.0 & 76.2 \\
\hline Greece & 19.0 & 13.9 & 5.0 & 12.6 \\
\hline Croatia & 19.9 & 16.2 & 53.1 & 29.7 \\
\hline Hungary & 20.8 & 56.0 & 39.7 & 38.8 \\
\hline Ireland & 11.8 & 76.3 & 13.8 & 34.0 \\
\hline Italy & 30.0 & 46.9 & 50.3 & 42.4 \\
\hline Lithuania & 11.6 & 10.9 & 51.4 & 24.6 \\
\hline Luxembourg & 17.4 & 52.9 & 122.4 & 64.2 \\
\hline Latvia & 36.9 & 16.3 & 53.0 & 35.4 \\
\hline Malta & 7.2 & 27.1 & 132.5 & 55.6 \\
\hline Netherlands & 22.5 & 93.1 & 59.6 & 58.4 \\
\hline Poland & 35.4 & 19.4 & 50.1 & 35.0 \\
\hline Portugal & 17.9 & 8.4 & 91.7 & 39.3 \\
\hline Romania & 20.0 & 21.5 & 64.0 & 35.2 \\
\hline Slovak Republic & 9.4 & 1.1 & 68.5 & 26.3 \\
\hline Slovenia & 60.7 & 22.4 & 111.6 & 64.9 \\
\hline Sweden & 41.0 & 76.8 & 52.9 & 56.9 \\
\hline Albania & 0.6 & 4.4 & 49.9 & 18.3 \\
\hline$B \& H$ & 1.3 & 25.3 & 17.9 & 14.8 \\
\hline N.Macedonia & 12.1 & 19.6 & 96.9 & 42.9 \\
\hline Montenegro & 19.1 & 6.4 & & 8.5 \\
\hline Serbia & 15.8 & 26.0 & 43.7 & 28.5 \\
\hline
\end{tabular}

Source: author's calculation according to World Bank data 
Table 4: Knowledge and technology absorption and diffusion index of EU and Western Balkan countries in 2020 Table: Knowledge and technology absorption and diffusion index of EU and Western Balkan countries in 2020

\begin{tabular}{|c|c|c|c|c|}
\hline & $\begin{array}{l}\text { Knowledge } \\
\text { absorption } \\
\text { index }\end{array}$ & $\begin{array}{c}\text { Knowledge } \\
\text { diffusion index }\end{array}$ & $\begin{array}{c}\text { Knowledge } \\
\text { and } \\
\text { technology } \\
\text { absorption } \\
\text { and diffusion } \\
\text { index } \\
\end{array}$ & $\begin{array}{c}\text { GDP per } \\
\text { capita, } \\
\text { PPPS }\end{array}$ \\
\hline Austria & 40.9 & 37.6 & 39.3 & 46,758 \\
\hline Belgium & 38.3 & 39.6 & 39.0 & 43,240 \\
\hline Bulgaria & 32.7 & 35.3 & 34.0 & 21,472 \\
\hline Cyprus & 40.3 & 54.2 & 47.3 & 36,149 \\
\hline Czech R. & 43.5 & 33.0 & 38.3 & 33,903 \\
\hline Germany & 42.5 & 45.8 & 44.2 & 46,766 \\
\hline Denmark & 40.9 & 42.5 & 41.7 & 47,040 \\
\hline Spain & 35.0 & 34.7 & 34.9 & 36,311 \\
\hline Estonia & 32.7 & 41.8 & 37.3 & 31,301 \\
\hline Finland & 44.2 & 65.9 & 55.1 & 41,883 \\
\hline France & 48.1 & 49.1 & 48.6 & 41,227 \\
\hline Greece & 24.5 & 22.3 & 23.4 & 26,411 \\
\hline Croatia & 28.7 & 30.9 & 29.8 & 24,208 \\
\hline Hungary & 48.1 & 44.6 & 46.4 & 29,723 \\
\hline Ireland & 60.3 & 86.4 & 73.4 & 72,810 \\
\hline Italy & 33.9 & 32.1 & 33.0 & 35,332 \\
\hline Lithuania & 24.0 & 30.0 & 27.0 & 32,041 \\
\hline Luxembourg & 54.0 & 37.0 & 45.5 & 95,117 \\
\hline Latvia & 31.1 & 42.7 & 36.9 & 27,415 \\
\hline Malta & 52.2 & 27.5 & 39.9 & 41,386 \\
\hline Netherlands & 77.9 & 79.7 & 78.8 & 50,933 \\
\hline Poland & 39.4 & 35.3 & 37.4 & 29,587 \\
\hline Portugal & 31.7 & 26.0 & 28.9 & 29,391 \\
\hline Romania & 34.4 & 43.3 & 38.9 & 24,443 \\
\hline Slovak Republic & 32.5 & 34.3 & 33.4 & 31,988 \\
\hline Slovenia & 37.2 & 28.7 & 33.0 & 33,579 \\
\hline Sweden & 51.0 & 63.9 & 57.5 & 47,692 \\
\hline Albania & 19.0 & 12.1 & 15.6 & 12,215 \\
\hline$B \& H$ & 15.7 & 25.3 & 20.5 & 12,414 \\
\hline N.Macedonia & 26.2 & 16.4 & 21.3 & 14,393 \\
\hline Montenegro & 24.3 & 16.5 & 20.4 & 17,534 \\
\hline Serbia & 25.4 & 33.0 & 29.2 & 16,207 \\
\hline
\end{tabular}

Source: author's calculation according to World Bank data 